\title{
Analysis of mercury in Malaysian herbal preparations
}

\author{
HH Ang ${ }^{1}$ and KL Lee ${ }^{1}$
}

\begin{abstract}
The DCA (Drug Control Authority) in Malaysia started implementing the phase three registration of traditional medicines on 1st January 1992 with special emphasis on the quality, efficacy and safety in all pharmaceutical dosage forms of traditional medicinal preparations. The rhizome of Smilax luzonensis is eaten as an aphrodisiac in the Malaysian community. This study was conducted to analyse the mercury content of 100 pharmaceutical dosage forms of S. luzonensis that were purchased in the Malaysian market, using cold vapour atomic absorption spectrophotometer. Results show that $86 \%$ of the products complied with the quality requirement for traditional medicinal preparations in Malaysia with particular reference to mercury content. Mercury, which has adverse effect on the male reproductive system, is present in $14 \%$ of the products examined, which calls for urgent action by the Malaysian government towards rectifying the abnormality.
\end{abstract}

\section{INTRODUCTION}

The use of traditional and alternative medicine has increased worldwide. ${ }^{1-11}$ However, the safety of alternative medicinal preparations for use has been questioned due to reports of unwanted side effects. ${ }^{12-18}$ Therefore, a critical evaluation of their safety for use is extremely important. ${ }^{8,18,19}$

The Malaysia government started implementing the phase three registration of

KEY WORDS:

${ }^{1}$ School of Pharmaceutical Sciences, Universiti Sains Malaysia, Minden, 11800, Penang, Malaysia.

Correspondence: Dr H. H. Ang, Associate Professor, School of Pharmaceutical Sciences, Universiti Sains Malaysia, Minden, 11800, Penang, Malaysia. Tel: 04-6533888 ext. 2264; Fax: 04-6570017; E-mail: hhang@usm.my

(C) CMS UNIBEN JMBR 2005; 4(1): 31-36 traditional medicines on 1st January 1992 under the Control of Drugs and Cosmetics Regulation 1984. The regulation emphasises quality, efficacy and safety (including the detection of the presence of heavy metals) in all pharmaceutical dosage forms of traditional medicinal preparations., ${ }^{8,20-22}$

Malaysia is blessed with an abundance of varied medicinal plants, which places the country among the world's 12 mega biodiversity rich countries in terms of the number of plant species. ${ }^{23}$ One of these herbal remedies is Smilax luzonensis, commonly known as akar banar, ${ }^{23,24}$ akar gadong tikus, ${ }^{23,24}$ akar kelona betina, ${ }^{23}$ akar semenjoh, ${ }^{23}$ alik besi, ${ }^{24}$ banar, ${ }^{24}$ banar babi, ${ }^{23-25}$, canar babi, ${ }^{23}$ gadong jantan, ${ }^{23,25}$ gadong tikus, ${ }^{25}$ kelona betina, ${ }^{25}$ kijil, ${ }^{25}$ rancang tembaga, ${ }^{25}$ and semenjoh. ${ }^{25}$ The rhizomes of this plant are used as sexual tonics ${ }^{25}$ and as such various 
pharmaceutical preparations of the plant are available in the Malaysian market.

This study analysed the mercury content of 100 products (both registered and unregistered with the DCA Malaysia) in various pharmaceutical dosage forms of $S$. luzonensis using cold vapour atomic absorption spectrophotometer (CVAAS). The products were purchased in the Malaysian market using simple random sampling technique to ensure equal ${ }^{26}$ and unbiased ${ }^{27}$ selection of any sample.

\section{MATERIALS AND METHODS}

All reagents used in this study were of analytical grade: hydrochloric acid ( $\mathrm{HCl}) 37 \%$ (sp. gr. 1.33, Merck); nitric acid 65\% (sp. gr. 1.40, Merck); stannous chloride dihydrate (BDH, Prod. 10270) and mercury stock solution 1000ppm (BDH, prod. $141454 \mathrm{~K})$. All glass wares were soaked in aqua regia $\left(\mathrm{HCl}: \mathrm{HNO}_{3}=3: 2\right)^{28}$ for two hours and then washed with deionised water (Deioniser Elga B113) prior to use.

One hundred medicinal preparations of $S$. luzonensis, either in single or combined preparations (Tables 1 and 2), were digested using freshly prepared aqua regia wet digestion. Approximately $1.5 \mathrm{~g}$ of each sample was weighed and placed in $100 \mathrm{ml}$ quick fit round bottom flask, after which $25 \mathrm{ml}$ freshly prepared aqua regia was added. The mixture was then refluxed over water bath for 6-8 hours (or until the sample had completely dissolved in the aqua regia). The mixture was then allowed to cool and filtered; the residue was then washed with deionised water. The combined aqueous extract was then made up to $50 \mathrm{ml}$ with deionised water.

This extraction procedure was repeated for the same sample (replicate) and the blank (containing aqua regia only). Coarse particles such as tablets, pills or powders, capsules and other contents were grounded to fine powder or particles prior to wet digestion.

Following this, $1 \mathrm{ml}$ extract, blank or standard solution, was added to $70 \mathrm{ml}$ deionised water in $150 \mathrm{ml}$ quick fit conical flask. Water was then added up to $2 \mathrm{ml}$ of $10 \%$ stannous chloride and aspirated by gas stream into the flameless pathway of the monochromatic light of GBC 906 AA model atomic absorption spectrophotometer (complete with in-built window-based 906 programme software). The absorbance was recorded when stable and the data were analysed. The operating procedures used were slit width: $0.5 \mathrm{~nm}$, current: $3.0 \mathrm{~mA}$ and wavelength: $253.7 \mathrm{~nm}$.

Then $10 \mathrm{~g}$ stannous chloride dihydrate $\left(\mathrm{SnCl}_{2} \cdot 2 \mathrm{H}_{2} \mathrm{O}\right)$ was dissolved in $20 \mathrm{ml}$ hot concentrated $\mathrm{HCl}$ and diluted to $100 \mathrm{ml}$ with deionised water. The resulting solution was heated with a metallic tin until the precipitate disappeared. It was stored in a glass bottle containing tin powder.

Mercury stock solution (1000ppm) was diluted serially to produce a standard solution of $0.1 \mu \mathrm{g} / \mathrm{ml}$. This was followed by adding $70 \mathrm{ml}$ deionised water into each of the seven $150 \mathrm{ml}$ quick fit conical flasks. They were then added to $0,0.5,1.0,1.5,2.0,2.5$ and $3.0 \mathrm{ml} 0.1 \mu \mathrm{g} / \mathrm{ml}$ of mercury stock solution to produce $0,0.05$, $0.1,0.15,0.2,0.25$ and $0.30 \mu \mathrm{g}$ of mercury respectively. Also, $2 \mathrm{ml}$ of $10 \%$ stannous chloride was added to each flask, after which they were aspirated by a gas stream into the flameless pathway of the monochromatic light. Absorbance was recorded when stable and the data were analysed.

\section{RESULTS}

\section{Mercury content evaluation}

Table 1 shows that 14 out of the 100 products (14\%) contained 0.51-1.23ppm mercury and, therefore, do not comply with the quality requirement for traditional medicines in Malaysia, which should not exceed $0.5 \mathrm{ppm}$ for mercury. ${ }^{30-33}$ Six of the 14 products were already registered with the DCA Malaysia; these were capsule rancang tembaga extra (0.51 $\pm 0.21 \mathrm{ppm}$ mercury), ace capsule rancang tembaga $(0.53 \pm 0.12 \mathrm{ppm}$ mercury), ummira rancang tembaga plus (0.68 \pm 
Table 1 Content of mercury in S. Iuzonensis preparations in Malaysia

\begin{tabular}{lccc}
\hline $\begin{array}{l}\text { Status of } \\
\text { registration }\end{array}$ & $\begin{array}{c}\text { Number } \\
\text { complying }^{\mathrm{a}}\end{array}$ & $\begin{array}{c}\text { Number not } \\
\text { complying }^{\mathrm{a}}\end{array}$ & Total \\
\hline Registered & $14^{\mathrm{b}}$ & $6^{\mathrm{c}}$ & 20 \\
Unregistered & $72^{\mathrm{b}}$ & $8^{\mathrm{d}}$ & 80 \\
\hline
\end{tabular}

${ }_{a} \leq 0.5 p p m$ mercury ${ }^{30-33} ; b \leq 0.5 p p m$ mercury; ${ }^{c o} .51-0.68 p p m$ mercury; ${ }^{\text {do }} .56-1.23 p p m$ mercury

Detection limit is defined as the concentration that will produce an absorbance signal three times the standard deviation of the blank. ${ }^{29}$

Detection limit (instrument and sample) $=$ Detection limit of instrument $x$ dilution factor

$$
=0.1 \mathrm{ppm}
$$

Sample weight

$0.11 \mathrm{ppm}$ mercury), gold box rancang tembaga plus (0.62 \pm 0.12 ppm mercury), maajun pak tani rancang tembaga $(0.61 \pm 0.12 \mathrm{ppm}$ mercury) and maajun petani rancang tembaga (0.56 $\pm 0.21 \mathrm{ppm}$ mercury).

The remaining eight of the 14 products were available in the Malaysian market nationwide but were not registered with the DCA Malaysia. These were: super capsule rancang tembaga $(0.70 \pm 0.03 \mathrm{ppm}$ mercury), great capsule rancang tembaga (0.63 \pm $0.12 \mathrm{ppm}$ mercury), tender capsule rancang tembaga ( $0.73 \pm 0.12 \mathrm{ppm}$ mercury), extra capsule rancang tembaga $(0.56 \pm 0.12 \mathrm{ppm}$ mercury), force capsule rancang tembaga (1.23 \pm $0.23 \mathrm{ppm}$ mercury), super capsule rancang tembaga plus ( $0.61 \pm 0.24 \mathrm{ppm}$ mercury), force capsule rancang tembaga plus $(0.78 \pm 0.11 \mathrm{ppm}$ mercury) and jiwa super capsule rancang tembaga (0.88 \pm 0.12 ppm mercury).

Only $86 \%$ of the products available in Malaysian markets complied with the maximum level of mercury content required for traditional medicines in Malaysia.

\section{DISCUSSION}

The use of aqua regia in acid digestion could ensure total extraction of metals from both inorganic and organic samples and virtually eliminates loss of mercury, compared to conventional wet digestion. ${ }^{34}$ CVAAS is the predominant technique for mercury analysis, ${ }^{29,35-38}$ due to its high selectivity and sensitivity. The sensitivity of the CV technique is far greater than can be achieved by the conventional AAS because it has $100 \%$ sampling efficiency, since all the mercury in the sample solution placed in the reaction flask is chemically atomised and transported to the sample cell for measurement. ${ }^{29}$

The general belief that herbal preparations are natural and, therefore, inherently safe, ${ }^{39-41}$ harmless ${ }^{42}$ and without any adverse effects is sometimes unfounded. ${ }^{22}$ Toxic effects of herbal preparations have been attributed to several factors including contamination by mercury. Mercury poisoning through traditional Chinese, ${ }^{43-47}$ Indian ${ }^{48,49}$ and Malaysian $^{50}$ medicines have been reported. In addition, mercury is capable of inducing sperm abnormality in human, ${ }^{51}$ whilst higher blood mercury concentration is associated with male infertility. ${ }^{52}$ Other studies have shown that membranes of acrosomal cap, the midpiece and the tail of human sperm are potential binding sites for mercury. ${ }^{53}$

Therefore, the DCA Malaysia has specified that the validity of pharmaceutical products (non-poisons) should be limited to a maximum of five years. Applicants will have to submit an application for re-registration and reassessment of the quality, efficacy and safety of their products. In addition, the DCA may reject, cancel or suspend the registration of any product if the need arises. ${ }^{54}$ 
34 Journal of Medicine and Biomedical Research

\section{ACKNOWLEDGEMENT}

This work was supported by a research grant from the Universiti Sains Malaysia (304/ PFARMASI/633118).

\section{References}

1. MacLennan AH, Wilson DH and Taylor AW. Prevalence and cost of alternative medicine in Australia. Lancet 1996; 347: 569-573.

2. Drew AK and Myers SP. Safety issues in herbal medicine: implications for the health professions. Med J Aust 1997; 166: 538-541.

3. Eisenberg D, David RB, Ettner SL, Appel S, Wilkey S, Rompay MV and Kessler RC. Trends in alternative medicine use in the United States, 1990?1997. JAMA 1998; 280: 1569-75.

4. Woods PW. Herbal healing. Essence 1999; 30: 42-46.

5. Ernst E and White AR. The BBC survey of complementary medicine use in the UK. Complement Ther Med 2000; 8: 32-36.

6. Ernst E. The role of complementary and alternative medicine. $\mathrm{Br}$ Med $\mathrm{J}$ 2000; 321: 1133-1135.

7. Khan IA, Allgood J, Walker LA, Abourashed EA, Schelenk D and Benson WH. Determination of heavy metals and pesticides in ginseng products. J AOAC 2001; 84: 936-939.

8. Mohamad Taha A. Traditional/complementary medicine in the Malaysian healthcare system. Keynote address presented at the 4th International Conference for Traditional/Complementary Medicine, Sunway Pyramid Convention Centre, 14 October 2002.

9. WHO. Drug Information. Herbal Medicines. Volume 16. Geneva: World Health Organization, 2002.

10. Zaidi II. Herbal products enjoying growing demand. In: Dr Lim (Ed.). The New Straits Times 2002; 21 August, B6.

11. Saras L. Protect traditional medicine industry. Medical Tribune 1?15 February 2003, p 5.

12. Saxe TG. Toxicity of medicinal herbal preparations. Am Fam Phys 1987; 5: 135-142.
13. Chan TY. Monitoring the safety of herbal medicines. Drug Safety 1997; 17: 209-215.

14. Cupp MJ. Herbal remedies: adverse effects and drug interaction. Am Fam Phys 1999; 59: 1239-1245.

15. Borins $\mathbf{M}$. The dangers of using herbs. What your patients need to know. Postgrad Med 1998; 104: 91-95.

16. Shaw D, Murray V and Volans G. Adverse effects of herbal remedies and OTC medicines. Br J Clin Pharmacol 1999; 47: 227228.

17. Stewart MJ, Moar JJ, Steenkamp P and Kokot M. Findings in fatal cases of poisoning attributed to traditional remedies in South Africa. Forensic Sci Int 1999; 101: 177-183.

18. Shamala G. Concern over safety of herbal remedies. The Sun 3 June 2001, p 15.

19. Ernst E. Toxic heavy metals and undeclared drugs in Asian herbal medicines. Trends Pharmacol Sci 2002; 23: 136-139.

20. Ministry of Health. Guidelines for application for registration of pharma-ceutical products (containing scheduled poisons and nonscheduled poisons). National Pharmaceutical Control Bureau, Ministry of Health, Kuala Lumpur, Malaysia, 1993: 7.

21. Guidelines on good manufacturing practice (GMP) for traditional medicines. National Pharmaceutical Control Bureau, Ministry of Health, Kuala Lumpur, Malaysia, 1999, 24.

22. Ramli AG. Regulatory control on toxic heavy metals and therapeutic drugs. Paper presented at the 3rd International Congress of the Asia Pacific Association of Medical Toxicology, Bayview Beach Resort, Penang, Malaysia, 12-15 November 2001; Abstract 95.

23. Herbal Medicine Research Group. Compendium of Medicinal Plants used in Malaysia. Kuala Lumpur: Institute for Medical Research, Malaysia, 2002, 345 Herbal Medicine Research Group 346.

24. De Padua LS, Bunyapraphatsara N and Lemmens RHMJ. Plants Resources of SouthEast Asia. Leidens: Backhuys Publishers, 1999; 452.

25. Kamarudin MS and Latiff A. Tumbuhan Ubatan Malaysia. Malaysia: Universiti Kebangsaan Malaysia and Ministry of Sci- 
ence, Technology and Environment, 2002; 626-627.

26. Newman EJ. Quality in the Analytical Chemistry Laboratory. John Wiley \& Sons, 1995; 38.

27. Schefler WC. Statistics for Health Professionals. Massachusetts: Addison-Wesley Publishing Company, 1984; 110.

28. Sastre J, Sahuquillo A, Vidal M and Rauret $\mathrm{G}$. Determination of $\mathrm{Cd}, \mathrm{Cu}, \mathrm{Pb}$ and $\mathrm{Zn}$ in environmental samples: microwave-assisted total digestion versus aqua regia and nitric acid extraction. Anal Chim Acta 2002; 462: 59-72.

29. Beaty RD and Kerber JD. Concepts, Instrumentation and Techniques in Atomic Absorption Spectrophotometry. Connecticut: Perkin-Elmer Corporation, 1993.

30. Jaafar L. Penilaian kualiti ubat-ubatan tradisional untuk ujian pendaftaran. (Evaluation of the quality of traditional medicines for testing prior to registration). Proceedings of the National Convention for Medicinal Plants, Forest Research Institute Malaysia, Kuala Lumpur, Malaysia, 13-15 October 1995, 41-47.

31. http://www.bpfk.gov.my/default.asp (Verified on 1 May 2004).

32. http://www.bpfk.gov.my/FAQ.htm (Verified on 1 May 2004).

33. Regulating supplements. The Star 8 June 2003; 14.

34. Lee DC and Laufmann CW. Determination of submicrogram quantities of mercury in pulp and paper board by flameless atomic absorption spectrometry. Anal Chem 1971; 43: 1127-1129.

35. Environmental Protection Agency. EPA Test Methods for Evaluating Solid Waste: Volume 1A: Laboratory Manual Physical/Chemical Methods. Washington DC: Environmental Protection Agency, 1986.

36. Adeloju SB, Dhindsa HS and Tandon RK. Evaluation of some wet decomposition methods for mercury determination in biological and environmental materials by cold vapor atomic absorption spectroscopy. Anal Chim Acta 1994; 285: 359-364.

37. Bruhn CG, Rodriguez AA, Barrios C and

(C) CMS UNIBEN JMBR 2005; 4(1): 31-36
Jaramillo VH. Determination of total mercury in scalp hair of humans by gold amalgamation cold vapour atomic absorption spectrometry. J Anal Atomic Spectrom 1994; 9: 535-541.

38. Landi S and Fagioli F. The adaptation of the dichromate digestion method for total mercury determination by cold vapor atomic absorption spectrometry to the analysis of soils, sediments and sludges. Anal Chim Acta 1994; 298: 363-374.

39. Capasso R, Izzo AA, Pinto L, Bifulco T, Vitobello $C$ and Mascolo N. Phytotherapy and quality of herbal medicines. Fitoterapia 2000; 71: S58-S65.

40. Friedman RA. ?Natural? doesn't mean safe. The New York Times 19 April 1996; A29.

41. Ernst E. Why complementary medicine? Perfusion 1999; 11: 437.

42. Bateman J, Chapman RD and Simpson D. Possible toxicity of herbal remedies. Scottish Med J 1998; 43: 7-15.

43. Kang-Yum E and Oransky SH. Chinese patent medicine as a potential source of mercury poisoning. Vet Hum Toxicol 1992; 34: 235-239.

44. Chi YW, Chen SL, Yang MH, Hwang RC and Chu ML. Heavy metals in traditional Chinese medicine: ba-pao-neu-hwang-san. Zhonghua Min Guo Xiao Er Ke Yi Xue Hui Za Zhi 1993; 34: 181-190.

45. Espinoza EO, Mann MJ and Bleasdell B. Arsenic and mercury in traditional Chinese herbal balls. $N$ Engl J Med 1995; 333: 803?804.

46. Li AM, Chan MH, Leung TF, Cheung RC, Lam CW and Fok TF. Mercury intoxication presenting with tics. Arch Dis Child 2000; 83: 174-175.

47. Ernst E. Adverse effects of herbal drugs in dermatology. Br J Dermatol 2000; 143: 923929.

48. Kew J, Morris C and Aihic A. Arsenic and mercury intoxication due to Indian ethnic remedies. $\mathrm{Br}$ Med J 1993; 306: 506-507.

49. Sheerin NS, Monk PN, Aslam M and Thurston H. Simultaneous exposure to lead, arsenic and mercury from Indian ethnic remedies. Br J Clin Pharmacol 1994; 48: 332-333.

50. Ahsan AA. Ubat tradisional turut rosakkan 
buah pinggang (traditional medicines cause kidney damage). Utusan Malaysia 5 August 2000; 2.

51. Ernst E and Lauritsen JG. Effect of organic and inorganic mercury on human sperm motility. Pharmacol Toxicol 1991; 68: 440444.

52. Choy CMY, Lam CWK, Cheung LTF, BritonJones CM, Cheung LP and Haines CJ. Infertility, blood mercury concentrations and dietary seafood consumption: a case-control study. Int J Obstet Gynaecol 2002; 109: 1121-1125.

53. Ernst E, Christensen M and Lauritsen JG. In vitro exposure of human spermatozoa to mercuric chloride - a histochemical study. Prog Histochem Cytochem 1991; 23: 263-268.

54. Newsletter of the Drug Control Authority Malaysia. National Pharmaceutical Control Bureau, Ministry of Health, Kuala Lumpur, Malaysia, 2001; 18: 18-19. 